\title{
香川中央都市圈に抢ける交通流の諸特性 ならびに都市構成との関係に関する研究
}

\section{藤 目 節 夫*}

\begin{abstract}
香川中央都市圈1にに打けるパーソントリップのOD行列に対し，主成分分析を適用して流動パターンの設 定を試み，さらに回帰分析の手法を用いて，流動パターンと都市構成との間の有意な関係について交通目的 別に考察を行なった．その結果，1. 流動パターンは交通目的ごとに異なった形態を示し, 全目的の流動パ夕 一ンは個々の交通目的のそれとは一般には一致しない，2. 発生・吸収交通は，交通目的ごとにそれぞれ特定 の都市構成と密接な関係があり, 流動パターンはこれら都市構成の空間的分布と明確な対応関係を有する, ことなどが明らかとなった。
\end{abstract}

\section{I まえがき}

都市の有機体としての活動は，たんに都市を傋成 する諸要素の空間的な配置パターンによってのみ規 定されるのではなく，それらが都市交通により有機 的に結合されることによって保証されるのである. したがって，都市構造を把握する場合には，たんに 都市を構成する諸要素（都市構成）の空間的分布に のみ着目すべきではなく，その分布した都市構成が 都市交通により機能的にいかなるかたちで連結され ているか，という視点においても考察される必要が ある。

地理学においては，都市構成の空間的分布に着目 し, 等質地域を設定しょうとした試みは従来から数 多くなされてきた。この等質地域の研究に比較し, ある種の流動指標を用いて地域間の機能的な結合関 係を明らかにしょうとした機能地域に関する研究は， あまり多くない，この原因としては，流動に関する データの入手困難さと, 複雑な流動データの情報の 損失をできるだけ少なくして效率的に処理すること の困難さに起因するものといわれている (Goddard, $1970 ＼mathrm{~ 林 ， 1974 ） 。 し か し な か ゙ ら ， テ ゙ ー タ の 入 手 困 ~}$ 難さは徐及に解消され, 分析手法においても多变量 解析法を中心とする方法が用いられるようになり，

\footnotetext{
* 愛媛大学・法文学部
}

近年機能地域に関する研究がいくつかみられるよう になった. たとえば, Garrison \& Marble(1964)は, ベネズエラの航空網を連結行列(connection matrix) で表わし，これに対し因子分析を適用して機能地域 の設定を試みている. Illeris \& Pedersen (1968) は, デンマークの電話通話のデータに対し, 同じく因子 分析を適用して機能地域の設定を試みている. これ ら国家レベルの研究に対して, 比較的小地域を対象 とした研究は Goddard (1970), 奥野 (1972), 林 （1974，1975）などの研究がある. Goddard はロン ドン中心部のタクシー交通流のデータに対して, 林 は名古屋都市圈の自動車交通流のデータに対して, 因子分析を適用し機能地域の設定を試みている. 奥 野は中京圈の自動車交通流のデー夕に対して, 多変 量解析の手法を用いないで, 彼独自のユニークな手 法により中京地域の連結体系を明らかにしている.

このような一連の研究は, Goddard (1970) や林 (1974)が述べているように，たんに流動（交通流） パターンあるいは機能地域を設定することのみが目 的でなく，設定された機能地域を通じて地域構造を 解明することが目的である. 機能地域を通じて地域 構造を把握する場合, 重要なことは結合される地域 はいかなる目的をもった交通により結合されるのか， またその特定の目的を有する交通はいかなる袎能を もった都市構成相互を結合するのか，という関係を 
明確にすることである．なぜなら，特定の目的をも った交通が，特定の機能を有する都市構成相互を結 合するのであって，都市交通と都市構成は総体とし て関連するわけではないからである.この点に関し ては，Goddard (1970) も交通が目的別に取り扱われ ない限り, 流動パターンと都市内域における基礎単 位地区としての等質地域との間の有意な関係を統計 的に実証することは困難であると指摘している.

このような観点に立って従来の諸研究を概観した 場合，それらの多くは都市交通をたんに量として捉 えて都市構成との関連を考察しており，仮に上記の 問題点を指摘していても指摘にのみとどまり，実証 的な研究はなされていないただ Berry (1966)は， インド経済に括ける物資流動と空間構造に関する研 究において，因子分析や正準相関分析を通じて等質 地域と機能地域を設定し，物資流動パターンと社 会・経済活動の空間的分布との有意な関係を明らか にしているが，それは国家レベルの研究であって， 本研究で対象としているような都市レベルの研究で はない，したがって，従来の都市レベルの研究では， 都市交通の質（交通目的）に注目し，それと都市構 成との有意な関係は十分に考察されているとはいえ ないのである。

\section{II 研究目的}

従来の多くの研究では，地域間交通量などの流動 指標を質としてではなく量として捉え，都市構成と の関係を考察しょうとしてきた，その結果，流動指 標に基づく流動パターンは設定されても，そのパタ ーンが都市のいかなる機能を反映しているものであ るか，また都市構成との間の有意な関係はどのよう になっているのか，といった諸点については概観的 考察にとどまっている. 都市交通と都市構成の間の 関係について，奥野(1966)は次のような指摘をして いる.すなわち,「吸収交通は理由なくして吸収され るのではなく，交通が発生した地域では，その交通
の需要を満たすもののすべてが備わっていないで, 需要を満たすために他の地域に発生する．したがっ て，それを吸収する地域は，その需要に応に゙るたた りる施設があり，また，施設の種類によって吸収さ れる交通の質が異なる」.この奥野の指摘は，筆者 がここで指摘した点と本質的に等值である．すなわ ち，ひとくちに都市交通，都市構成といってもそれ ぞれに含まれる内容は多岐にわたっており，前者は 交通の質（交通目的）により，後者はその果たす機 能によって区別される必要がある.このような観点 に立って機能地域を設定し，それに基づいて都市構 造を考察することは，従来からの方法に比較して， より一層明確な都市の内部構造の把握が可能になる ものと考える.

以上のような考察により, 本研究に柇いては, 都 市の機能地域構造を明らかにするための1つの試み として次のような研究目的を設定した。

（1）交通目的別に流動パターンが異なることを前 提として，そのパターンを明確に捉え，交通の流動 パターンという側面から都市交通の特性を把握する。

（2）次に異なった流動パターンの現出は，多様な 都市構成の空間的分布の結果であるとの認識に基つ いて，両者の相互依存関係を明らかにする。

この研究目的へのアプローチとしては，(1）に対し ては目的別の流動データへ主成分分析を施し，従来 の，流動図の読み取りによる流動パターンの考察よ り明確にそのパターンを捉えることに努める。そし て，(2）に対しては，上述の主成分分析の結果から 抽出される主要な発・着地についてその地域特性を 取り上げ，それと流動パターンとの有意な関係を回 鹵分析によって考察することにする.

\section{III 研究地域と研笢資料}

1）研究地域の概要

流動指標に基づく流動パターンの設定，ならびに 流動パターンと都市構成との関係を考察しようとす 
る場合, 対象地域としては，(1) 中心商店街の成立, 近代的企業の成立などの地域分化がみられる都市で あり,さらに (2) 流動に関して対象地域内でかなり の完結性をもっていること，が必要である.

本研究では, 高松市, 丸亀市, 坂出市を中心とす る 3 市12町よりなる香川中央都市圈を調査対象地域 として設定した，対象地域の範囲は，昭和45年国勢 調查結果に基づく高松, 丸亀, 坂出の 3 市と牟礼町, 宇多津町への通勤・通学依存率が $20 \%$ を超す市町の うちから, 圈域の構成, 通勤・通学者数を勘案して 決定した(第 1 図)．この範囲は，高松市を中心とし た半径 $20 \sim 30 \mathrm{~km}$ に含をれる地域であるが，それは 香川中央都市圈パーソントリップ調查委員会が昭和 49 年度に実施したパーソントリップ調查の対象地 域と一致している.

この地域を研究対象としたのは，この地域が前出 の 2 つの条件をほぼ満足していると考えたからであ る.すなわち，この地域には四国の中枢管理機能を 有している高松市があり，地域分化が十分みられる こと, さらにこの地域で発生する通勤・通学交通 185, 542 トリップのうち，この地域で吸収されるの は(本地域への通勤・通学依存率) 182,192 トリップ

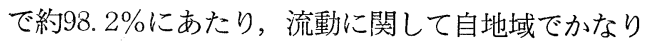
の完結性をもっていることによる.

2）研究資料の概要

研究目的に合致した分析資料として次のものを利 用した.

流動指標としては，人間の交通流（パーソントリ ップ）に関する資料を用いた．流動指標として何が 適切であるかについては従来多くの議論があり，同 時に種々の指標が用いられている22. 本研究で人間 の交通流を用いた理由は, Mitchell \& Rapkin (1954, p. 5) が指摘しているように, 人間の交通が都市交通 の最も基礎的かつ最も主体的なものである，と考え たからである. この流動指標は, 本研究の目的から 次のような内容を含んでいる必要がある，それはす
なわち，(1）地域間の人間の移動量，（2）その移動 の目的，に関する内容であるが，この目的に適した 資料は香川中央都市圈パーソントリップ調査委員会 によってまとめられた「交通目的別パーソントリッ プOD表」であり，本研究ではこれを分析資料とし て用いる.これは，昭和 49 年 10 月 1 日より 10 月 25日の間に行なわれた人間の移動に関する調査結果 であり, 調査対象地域 171,956 地帯，581, 378 人の それぞれ8.4\%，8.1\%にあたる14,442世帯，46,705 人に関するものである.これらは，通勤，通学，私 事, 業務などの交通目的別にOD表の形式で集計さ れている.

この他に，分析資料としては各単位地区（次節参 照）ごとの各種の都市構成要素に関する資料も用い た.これは，流動パターンと都市構成との関係を考 察するためのものである.

3）単位地区の設定

研究対象地域内部の基礎的な単位地区をどのよう に設定するかは困難な問題であるが，本研究では次 の諸点に留意して単位地区を設定した。すなわち,

（1）人口，土地利用等に関して等質性をなるべく満 足すること，(2）家庭訪問調査の精度を勘案し，人 口規模がほぼ均等であること，（3）人口・経済指標 等の既存統計資料が容易に利用しうるように単位地 区の境界は市・町や町丁界に一致すること，である.

以上の基準で単位地区を設定した結果, 高松市は 36 , 坂出市は11, 丸亀市は 7 の単位地区に区分され, その他の町はそれ自体で $1 つ の$ 単位地区となった。 したがって，都市圈内は66の単位地区に区分される ことになった(第1図).

\section{IV 交通目的別の流動パターン}

\section{1）分析方法}

既述したように，地理学の従来の研究でもある種 の流動指標を用いて地域間の結合関係（流動パター ン）を把握しょうとする方法がいくつか試みられて 


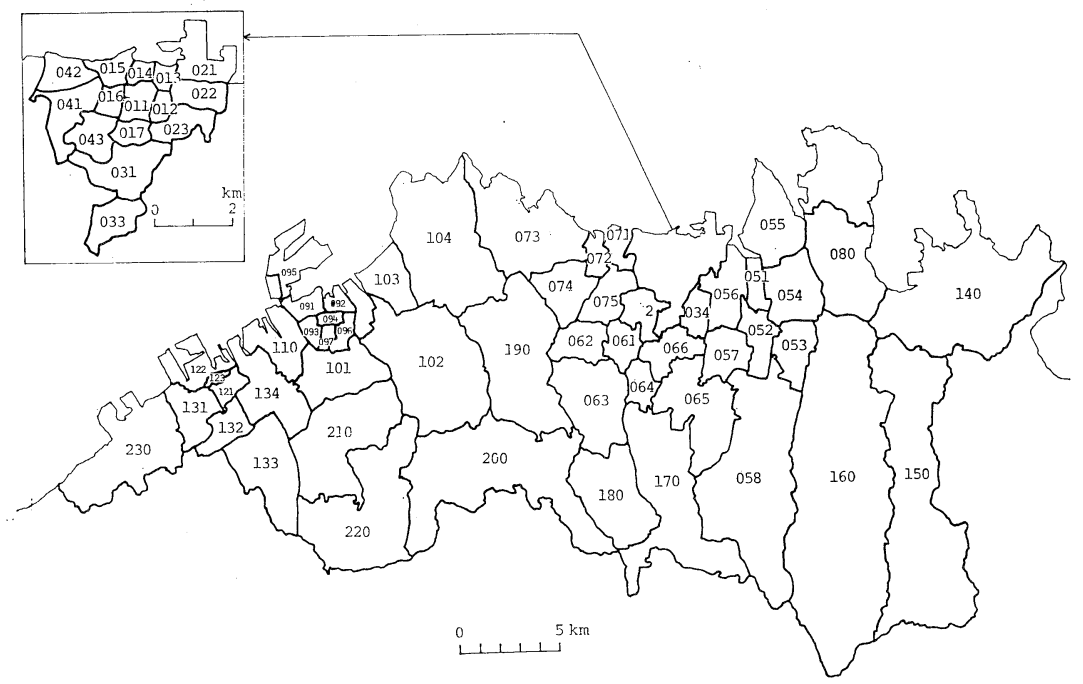

第 1 図単位地区区分図

011. 瓦町 012. 塩上町 013. 城東町 014. 寿町 015. 錦町 016. 番町 017. 中新町 021. 朝日町 022. 福岡町 023. 松島町 031. 栗林町 032. 西八ゼ町 033. 三条町 034. 松縄町 041. 昭和町 042. 瀬戸内町 043. 宮脇町 051. 春日町 052. 元山町 053. 前田西町 054. 高松町 055. 屋島中町 056. 木太町 057. 林町 058. 西植田町 061. 勅使町 062. 御廐町 063. 円座町 064. 一宫町 065. 仏生山町 066. 太田上町 071. 郷東町 072. 香西本町 073. 龟水町 074. 鬼無町 075. 鶴市町 080. 牟礼町 091. 築港町 092. 入船町 093. 白金町 094. 京町 095. 番の州町 096. 谷町 097. 青葉町 101. 川津町 102. 府中町 103. 林田町 104. 青梅町 110. 宇多津町 121. 一番町 122. 北平山町 123. 富屋町 131. 今津町 132. 田村町 133. 郡家町 134. 土器町 140. 志度町 150. 長尾町 160. 三木町 170. 香川町 180. 香南町 190. 国分寺町 200. 綾南町 210. 飯山町 220 . 綾歌町 230 . 多度津町 町名は各単位地区内の代表的なものを示す.

きた．分析手法からこれらをみると，(1）地図学的 方法，（2）グラフ理論による方法，（3）主成分分 析・因子分析による方法，などがある.これらの方 法はいずれも一長一短があるが，本研究では個々の 地区は複数の他の地区と関連し合っており, あらか じめ地域の階層性が仮定できない等の理由により， 主成分分析を適用して流動パターンを設定すること にした。

主成分分析の理論については，すでに数多くの文 献に紹介されているので，ここではその理論的背景 についての議論は省略し，主成分分析を OD行列に 適用する場合の具体的手順，結果の解釈，その有用 性について簡単に触れて抢きたい，主成分分析を OD 行列に適用する場合, 行に発地区，列に着地区 を配したデー夕行列に対してR-技法の分析が行な われる ${ }^{32}$. 解析の結果得られた各成分の解釈は，そ
の成分係数の值によって行なわれるが，解釈が困難 な場合には成分軸の回転が行なわれる. 本研究では, バリマックス回転を行なって成分の解釈を容易にし ている. その場合, 成分係数行列は着地区パターン を，成分得点行列は発地区パターンを示すことにな る. そして，ある成分に対して成分係数の值（絶対 值）が大きい地区は，その成分の意味するところの 重要な着地区を表わし，一方，その成分に対する成分 得点の值 (絶対值) が大きい地区は重要な発地区を 表わすと解釈される．このようにして得られた重要 な発地区群と着地区群を連結して得られる地域は， 人間の交通に関して統一性と完結性を有した機能地 域に相当すると解釈される.

ここで問題となるのは, 成分得点と成分係数の絶 対値がどの程度以上を重要な発・着地区とみなすか ということであるが，これについては確かな基準は 
第 1 表 成分係数, 成分得点一覧表

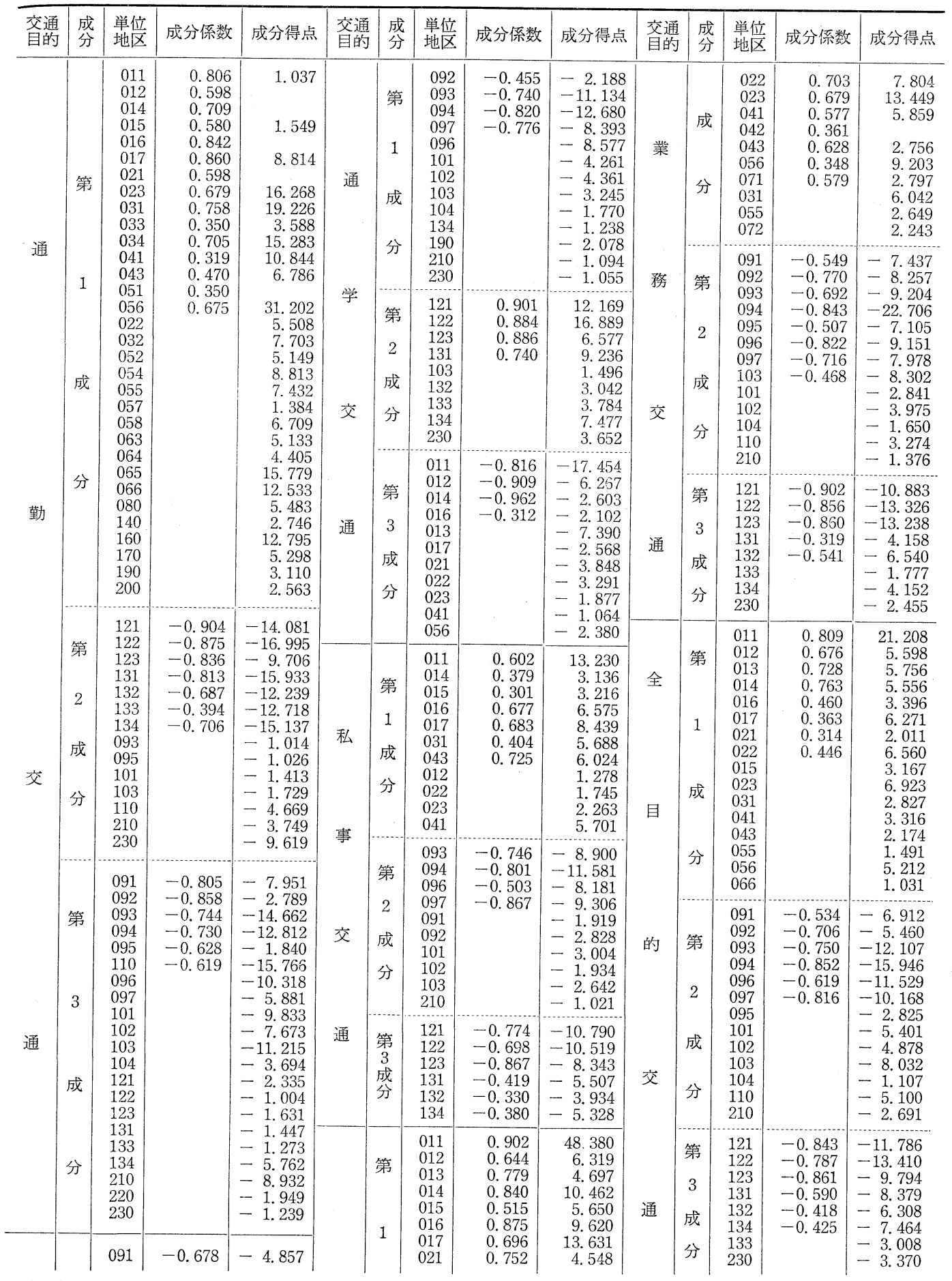

成分係数 $>|0.3|$, 成分得点 $>|1.0|$ の及表示.

単位地区番号は第 1 図を参照. 
設けられていない . 本研究の場合は, 成分得点と 成分係数の絶対値がそれぞれ 1.0 および 0.3 以上を 重要な発・着地区とみなして，流動パターンを設定 した.

2）交通目的別流動パターン

ここでは，上述の分析方法を目的別 OD交通量に 適用して流動パターンを設定し, 都市交通の特性を パターンという側面から考察する. 主成分分析を $\mathrm{OD}$ 行列に適用すると数多くの成分が得られるが， 一般に考察対象とされる成分は固有値 1.0 以上であ るとされている5)。本研究では，流動指標としてパ ーソントリップを用いている関係上, 変量(着地区) の要約が困難となり，したがって数多くの固有值 1. 0 以上の成分が抽出された ${ }^{6)}$. 本来はこれらすべ ての成分について考察を加えることが望ましいが， 今回は各交通目的について上位 3 成分に限定するこ とにした，その理由としては，(1）本研究の目的の $1 つ か ゙$ 交通目的別の流動パターンの差異を明らかに することであり，この点からみて変動説明量の高い 上位の成分に限定したほうがその差異を明確に促 えられる，(2）紙面の都合上，すべての成分につい て考察を加えることが困難，などによる．したがっ て，以下での結論は㛜密には上位 3 成分に限定され るが，それ以下の成分に対しても同様な議論が可能 である.

なお，考察対象とした上位 3 成分は，いずれの交 通目的に㧧いても, 高松市, 坂出市, 丸刍市の中心 部を表わす成分であった。

1. 通勤交通のパターン

通勤交通に対する主成分分析の結果，それから求 められた流動パターンは，それぞれ第1表および第 2 図に示す。

まず第 1 成分に着目すると，成分係数の値の大き い地区は, 中新町, 番町, 瓦町, 栗林町, 寿町な どフを中心にそのほとんどが高松旧市内の地区であ る.したがって，第 1 成分は高松旧市内の地区を他
の着地区と区別する成分と解釈される．これらの地 区は中枢管理的，商業・業務的機能が集積しており， その程度も都市圈内で最大である. したがって, 就 業機会も非常に大きいので第 1 成分の重要な着地区 になったものと考えられる.

一方，これに対し重要な発地区は，木太町，栗林 町，松島町，仏生山町，松縄町，太田上町などの高 松都心部周辺の地区であり，高松旧市内の地区はそ のほとんどが，さほど重要な発地区にはなっていな い.このことは，都心に職場をもつ者の多くが郊外 部に居住し，そこから都心へ出勤するという，都市 の通勤交通の特性をよく表わしている，重要な発地 区は，さらに広範囲にわたって抢り，東は志度町， 南は香川町，綾南町，西は国分寺町にまで及んでい る. このように，とくに重要な発・着地が地域的に 分離するという特性をもった流動パターンは，通勤 交通にしかみられない，この傾向は第 1 成分に沶い てとくに顕著である.

第 2 成分の成分係数の絶対值が大きい地区は，丸 亀市の一番町, 北平山町, 富屋町などであって, こ れらは丸亀市の中心部からなる。これらの地区では， 一番町は市役所を中心とする中枢管理的機能, 北平 山町は重化学工業, 富屋町は商業・業務的機能の集 積がそれぞれとくに顕著である。このように，各地 区はそれぞれの特色は異なるが，丸象市における就 業機会の最も大きな地域であり，したがって通勤交 通の重要な着地区になっているものと考えられる。

一方, 発地区をみると, とくに重要な発地区はと くに重要な着地区と一致している.この他にも重要 な発地区はいくつかあるが，多度津町以外は相対的 重要度はかなり低い：これは第 1 成分と著しく異な る特徴であるが，この原因は丸亀市において職住分 離があまりなされていない，換言すれば都市の機能 分化の程度が低いことに起因するものと考えられる。

第 3 成分の成分係数の絶対值が大きい地区は，坂 出市の入船町, 築港町, 白金町, 京町, 番の州町な 


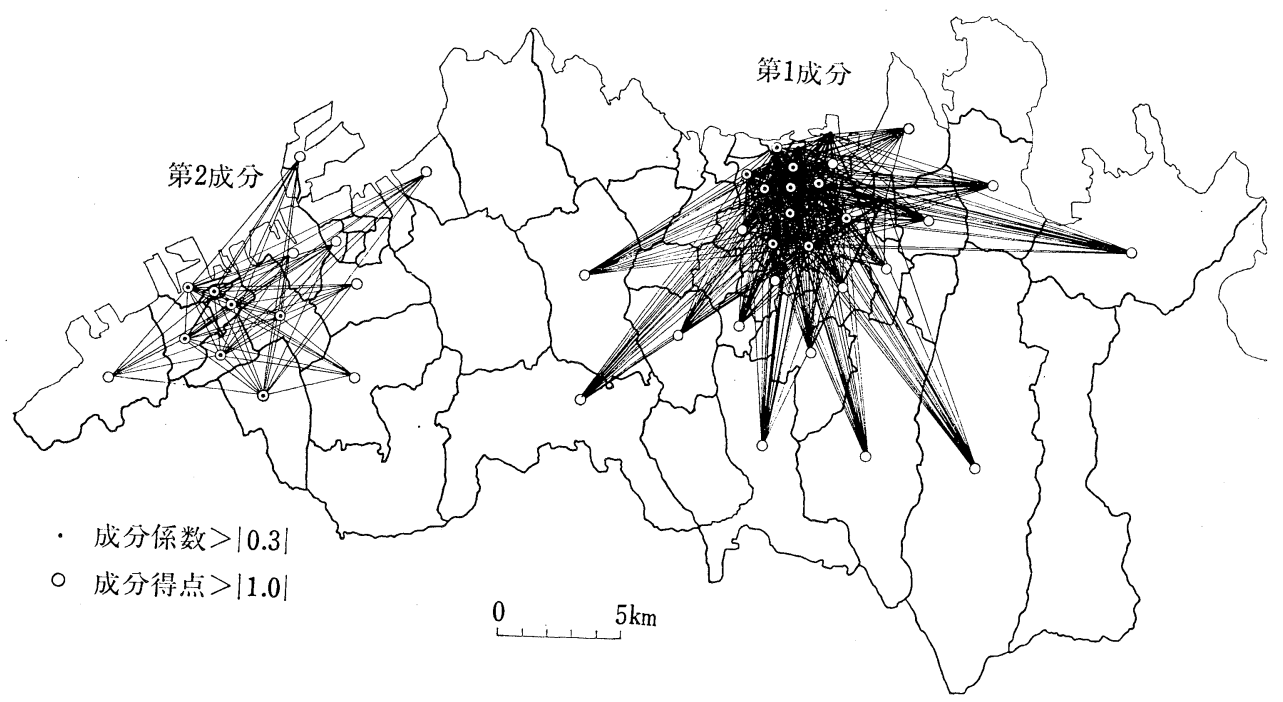

その 1

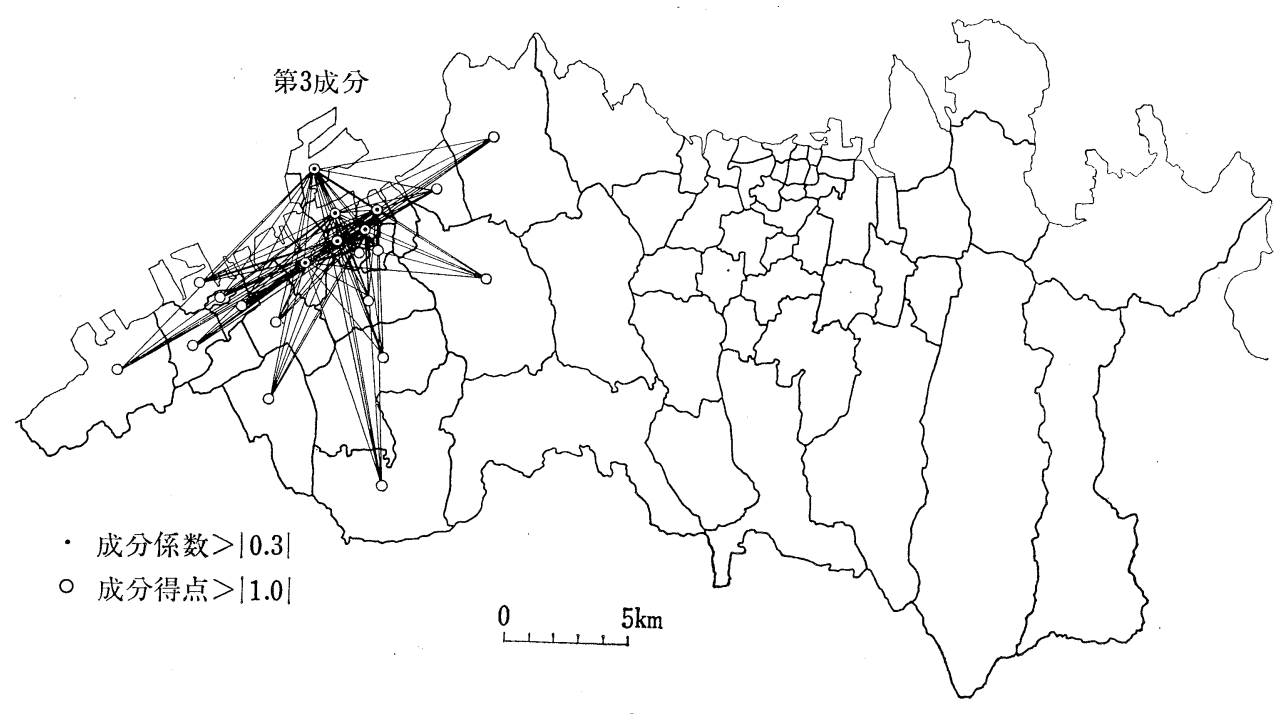

その 2

第 2 図通勤目的流動パターン

どであり，これらは国道11号線以南の坂出市街地と それ以北の臨海工業地域に大別できる．前者は中枢 管理, 商業的機能が, 後者は工業的機能が主に集積 しているという違いはあるが，両者とも就業機会が 大であるという点では共通しており，この結果重要 な着地区になったものと考えられる.

一方, 重要な発地区に着目すると, 重要な着地区
はすべて重要な発地区となっているが，そのうち入 船町, 番の州町はさほど重要ではなく, これらより も重要な着地区ではない林田町, 谷町, 川津町, 飯 山町などの周辺部が重要な発地区となっている.こ の結果を前述した機能分化という視点で捉えると， 坂出市は高松市ほどではないが，丸亀市以上に機能 分化が進んでいると考えられる. 


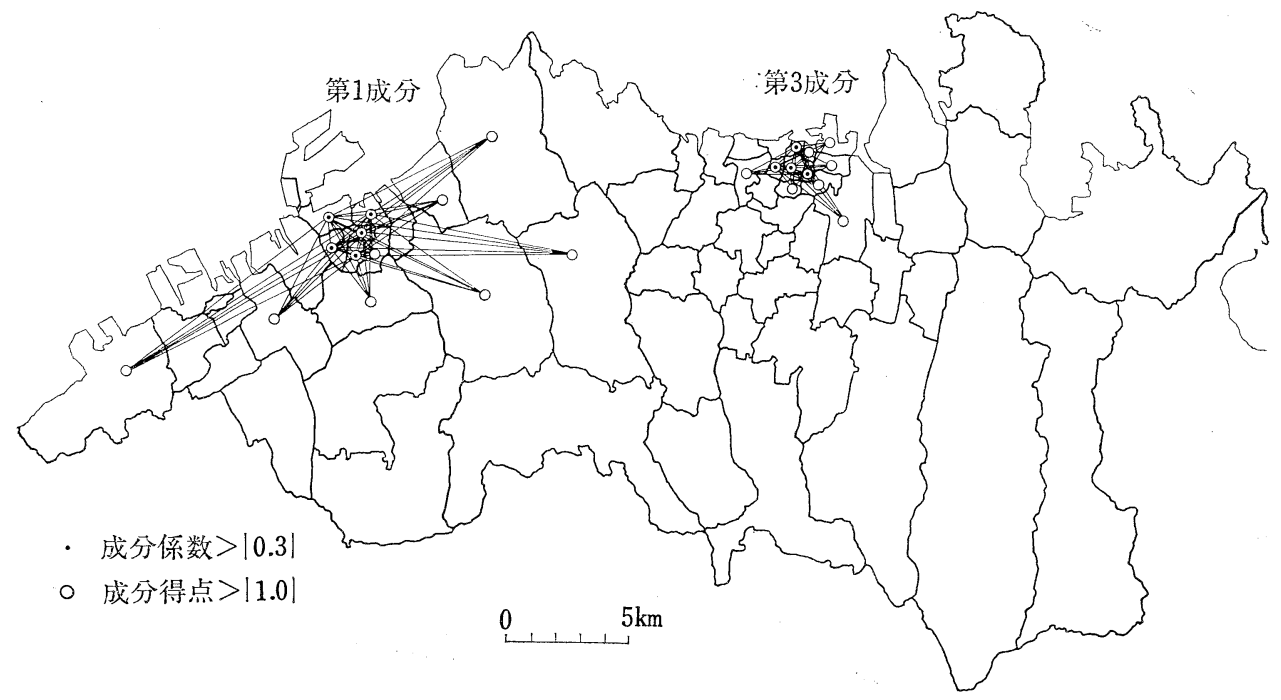

その 1

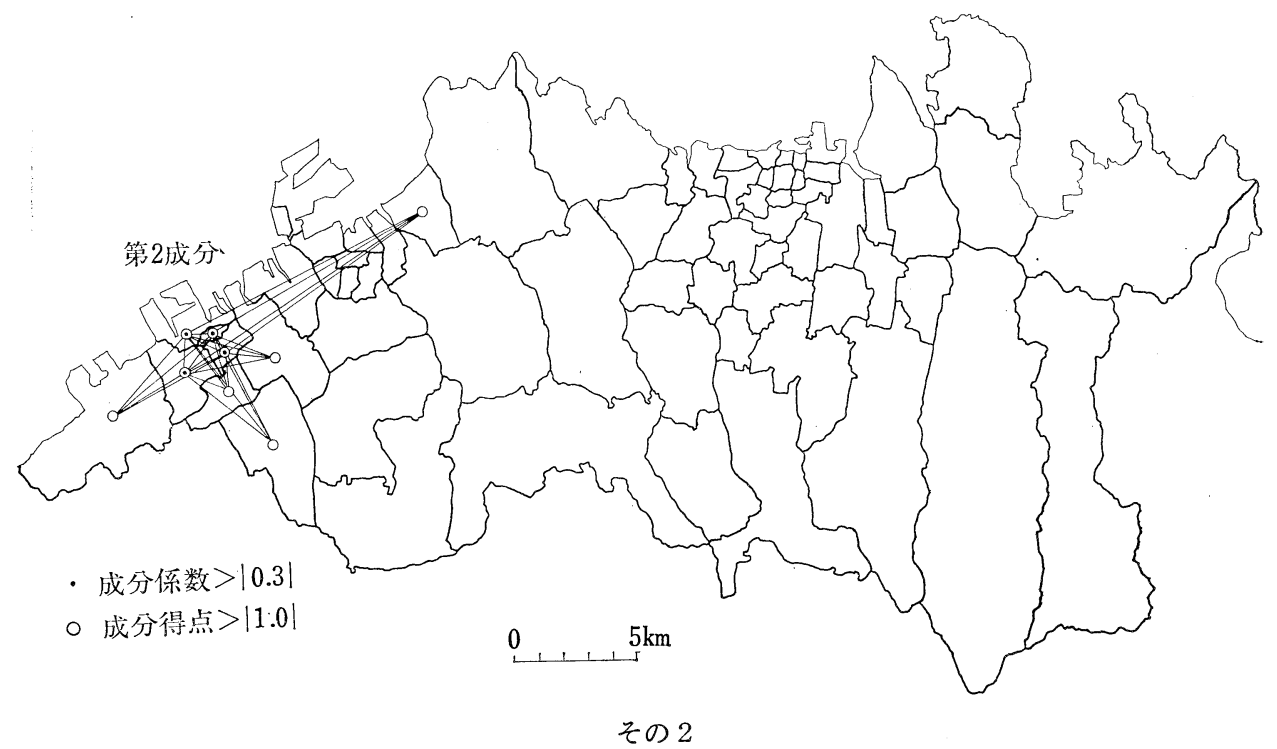

第 3 図通学目的流動パターン

以上のことから，通勤交通の流動パターンの特性 としては以下の諸点が指摘できる.

1. 通勤交通では重要な発・着地が空間的に広く 分布し，その結果，流動パターンも広範囲な広がり を呈する. すなわち, 都心部に重要な着地が, 郊外 部に重要な発地が位置し, 両者を結合するパターン は広範囲なものとなる。
2. しかし，この特性は都市の機能分化の程度に より異なり，機能分化の進んでいる都市ほど，とく に重要な発・着地がそれぞれ郊外と都心に分離して 分布するが，機能分化があまり進んでいない都市で は両者は一致する傾向がある.

2. 通学交通のパターン

通学交通に対する主成分分析の結果と，それから 
求められた流動パターンは，それぞれ第1表および 第 3 図に示す.

まず第 1 成分の成分係数の絶対値が大きい地区は， 京町, 青葉町, 白金町, 築港町などの坂出市の中心 部地区である. したがって，第 1 成分は坂出市の中 心部を他の着地区と区分する成分と解釈される，一 方，とくに重要な発地区は，これら重要な着地区と これらの地区に隣接する谷町とからなっている. 第 3図をみると，流動パターンはかなり広範囲にわた っているが，とくに重要な発・着地区は同一地区な いし隣接地区で形成されており，実質的には交通の 大半はこの狭い区域内でなされていると考えてよい であろう．これは学区制のため通学交通の移動範囲 が限定されるためと考えられる．重要な発地区では あるが重要な着地区ではない谷町は，夜間人口がか なり多いにもかかわらず金山小学校しかなく，した がって重要な着地区にはなっていない.このような 場合にのみ，とくに重要な発・着地が一致しないの が通学交通の特性である.

第 2 成分の成分係数の值が大きい地区は，一番町， 富屋町，北平山町，今津町であり，これらは丸亀市 の中心部地区である. 第 2 成分においても，とくに
重要な発・着地は同一地区ないし隣接地区で形成さ れており，第 1 成分と同様な特性が指摘できる.土 器町はとくに重要な発地区ではあるが，重要な着地 区とはなっていない，これは第 1 成分の谷町と同様 な理由による.

第 3 成分は，寿町，塩上町，瓦町など高松市中心 部と相関が高い，重要なすべての発地区は，これら の地区と隣接する地区とからなっており，流動パ夕 ーンとしては上位 3 成分において最も通学交通の特 性を示すものとなっている. すなわち，学校の存在 で重要となった着地区を中心にして隣接地区間での み流動パターンが形成されている．第 3 成分におい ても，城東町はとくに重要な発地区ではあるが，重 要な着地区となっていない，それはこの地区に学校 がまったく存在しないためである.

以上のことから, 通学交通の流動パターンの特性 としては以下の諸点が指摘できる.

1. とくに重要な発・着地区は，学区制のため同 一地区ないし隣接地区で形成されており，流動の主 要部分は学校を中心とする狭い範囲内に限定される。

2. とくに重要な発地区であるが重要な着地区で はない地区は，夜間人口に比較し学校が少ないか，

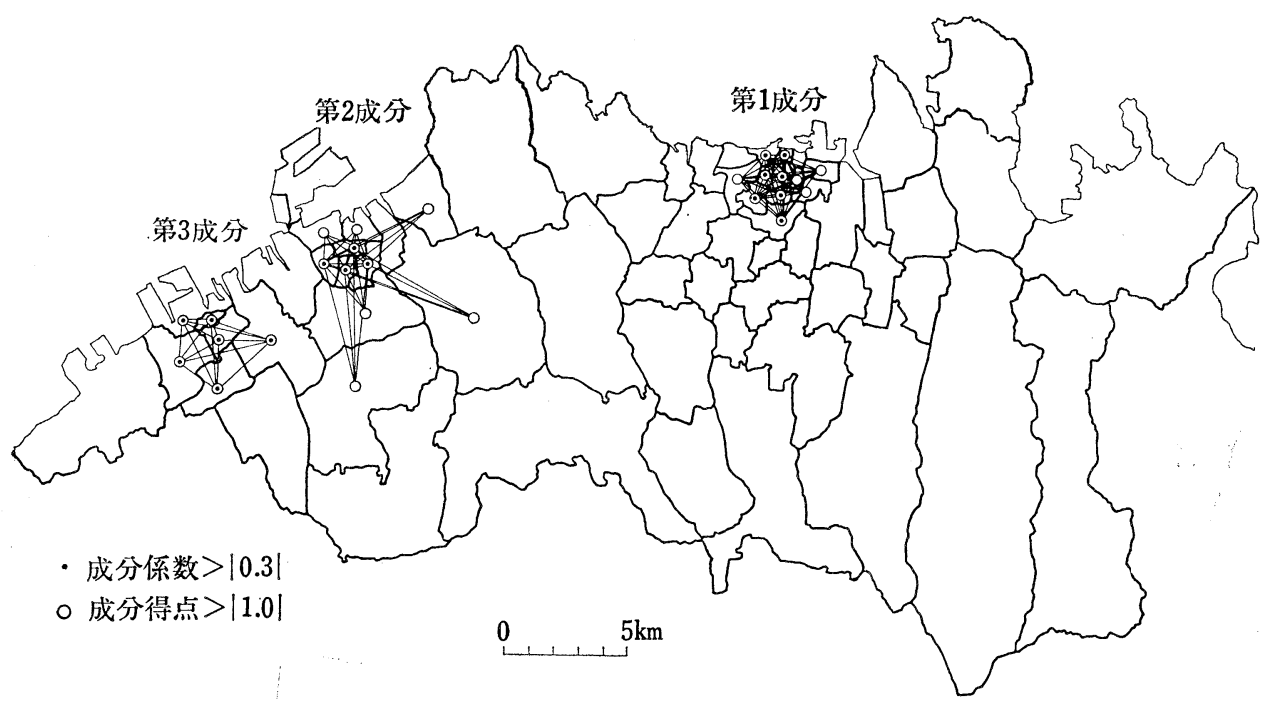

第 4 図私事目的流動パターン 
まったく存在しない場合に限られる.

3. 私事交通 ${ }^{8)}$ のパターン

私事交通に対する主成分分析の結果と，それから 求められた流動パターンは，それぞれ第 1 表および 第 4 図に示す.

まず第 1 成分についてみると，成分係数の大きい 地区は, 宮脇町, 中新町, 番町, 瓦町などの高松旧 市内のうち琴電琴平線の西側の地区であり, 高松築 港から栗林公園までに至る国道の沿線に南北に細長 く伸びている．この重要な着地区群は，通勤交通と 後述する業務交通の重要な着地区の一部，それも都 心部の地区から形成されている.これらの地区は， 私事交通の主要な着施設と考えられる商業・娛楽施 設が，瓦町，片原町，常盤町商店街などに代表され るように香川中央都市圈で最も集積しており，した がってこの地区が第 1 成分で重要な着地区となった ものと考えられる. 重要な発地区は，これらの地区 と隣接する地区から形成されており，その結果流動 パターンの広がりは第 1 成分としては極端に狭い.

第 2 成分と相関が高い地区は，青葉町, 京町, 白 金町，谷町などであり，これらは坂出市中心部のう ち国道11号線以南の地区を表わす。これらの地区も
第 1 成分の場合と同様, 商業・娛楽施設の集積した 地区であり，かつ通勤交通と業務交通の重要な着地 区の一部から形成されている. 重要な発地区は, こ れら以外にいくつかあるが，それらは相対的に重要 度が低く、したがってとくに重要な発・着地はほぼ 一致し，これらの地区間で主に私事交通がなされる と考えられる.

第 3 成分と相関が高い地区は，郡家町を除く丸亀 市全域であり, 一方, 重要な発地区はこれら着地区 と完全に一致する. したがって流動パターンは非常 に狭いものとなる. 第 3 成分の重要な着地区は, 通 勤交通と業務交通に打いて丸亀市を表わす成分の重 要な着地区とほぼ一致する傾向がある．これは第 1 , 第 2 成分にみられない特徵であるが，このことはれ 亀市の機能分化があまり進んでいないことに起因す るものと考えられる.

以上のことから, 私事交通の流動パターンの特性 としては以下の諸点が指摘できる。

1. 重要な発・着地はほぼ隣接した地区間で構成 されており，流動パターンの広がりはすべての目的 中最小である.

2. 重要な着地区は，都心部においてもとくに商

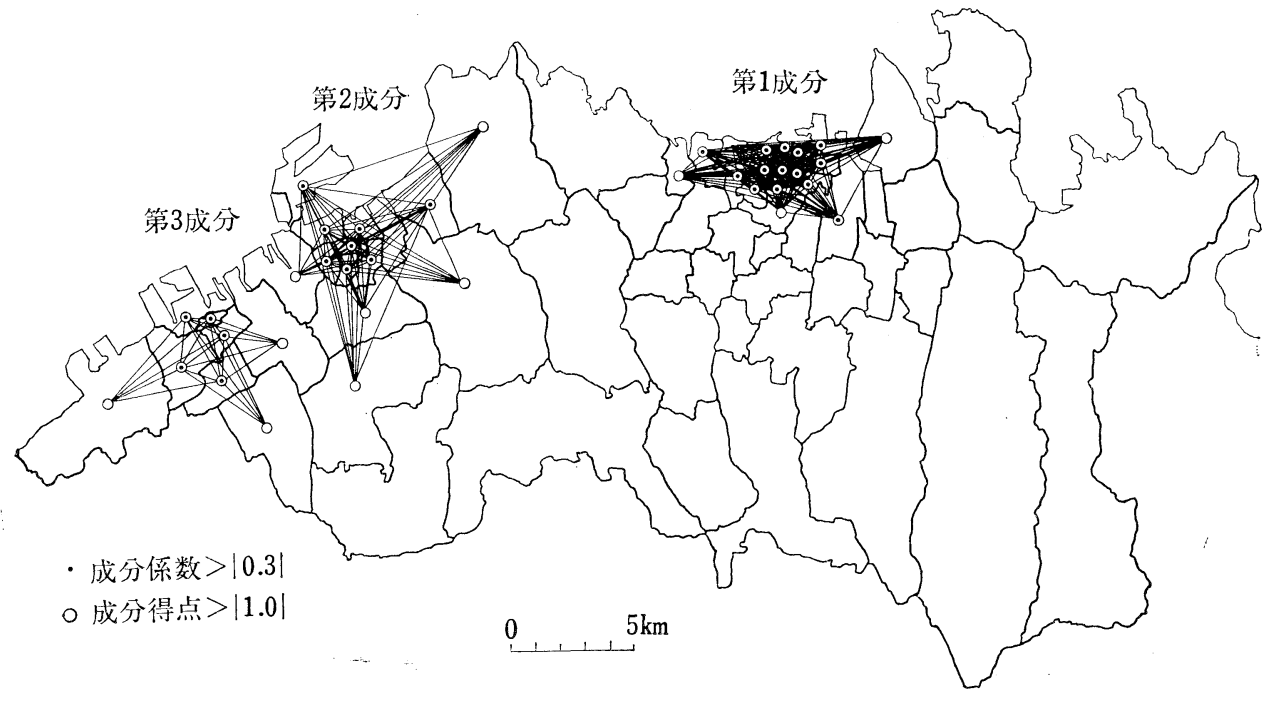

第 5 図業務目的流動パターン 
業・娛楽施設の集積した地区に限定され，一般に通 勤, 業務交通の重要な着地区の一部より形成される. しかし, 丸亀市のような機能分化があまり進んでい ない都市では，私事交通と通勤，業務交通の重要な 着地はほぼ一致する傾向がある。

4. 業務交通のパターン

業務交通に対する主成分分析の結果とそれから求 められた流動パターンは，それぞれ第1表および第 5 図に示す.

まず第 1 成分に着目すると, 成分係数の大きい地 区は, 瓦町, 番町, 寿町, 城東町などを中心にして ほぼ高松市中心部全域にわたって非常に多くの着地 区が抽出されている. 第1成分に扑ててのように 数多くの重要な着地区が抽出されるのは，他では通 勤交通だけであるが，その内容は若干異なる，すな わち, 通勤交通では南部の栗林町, 西八ゼ町等の地 区が含まれるのに対し，業務交通ではこれらは含ま れず，逆に昭和町，郷東町などの西部の地区が含ま れており, 着地区群は東西に広がって分布している. また，私事交通と比較すると，私事交通の重要な着 地区は商業・娛楽施設が集積している琴電琴平線西 部に限定されていたのに対し，業務交通ではこれら の地区を包含し，さらに東西の地区に及んでおり範 囲も広い: 業務交通における重要な着地区に関して 特徴的なことは，通勤または私事交通のいずれにお いても重要とならなかった地区が，業務交通におい て重要な着地区となっていることである. このよう な地区には, 城東町, 福岡町, 瀬戸内町, 郷東町な どがある.これらの地区に共通する特徴は，いずれ も商業販売額が高く，経済活動が活発であるという ことがある. 逆に, 通勤交通において重要な着地区 となっていながら，業務交通ではそうではない地区 としては, 栗林町, 三条町, 松縄町などがあり, こ れらはいずれも商業販売額が低くなっている. した がって, 通勤交通において重要となった着地区は, 一般に事業所施設が立地し, 業務交通においても重
要な着地区になると考えられるが，商業販売額が低 く経済活動のそれほど活発でない地区においてはこ の限りでないといえる. 一方, 重要な発地区に着目 すると, 数多くの重要な着地区が抽出されているに もかかわらず，重要な発地区はこれら以外にほとん どなく, 重要な発・着地はほぼ一致している。した がって，業務交通は重要な着地区間相互で主に交通 が行なわれると考えられる.

第 2 成分と相関が高い地区は，京町，谷町，入船 町, 青葉町などを中心とした坂出市の地区であり, 重要な着地区は8地区抽出されており，これは坂出 市を表わす成分では最高の数である. これらの着地 区群はその特性により 2 つ大大別できる. 1つは 11 号線以南の旧市街地地区であり, 他の 1 つは以北の 臨海部地区である．前者は主に商業に特化しており, 私事交通での重要な着地区と完全に一致する. 後者 は主に工業に特化しており, 通勤交通において重要 な着地区となっている.このように，両地区はその 特性は異なるが，いずれも経済活動の活発な地区で あり，したがって業務交通で重要な着地区になって いるものと考えられる. 一方, 重要な発地区は重要 な着地区以外にいくつかあるが，それらの相対的重 要度はかなり低く, 業務交通は重要な着地区間相互 で交通がなされていると考えられる.

第 3 成分については，丸亀市の中心部を表わす 5 地区が抽出されている。これらの地区は通勤，私事 交通に㧊いて，すべて重要な着地区となっている. したがって，流動パターンも交通目的によりそれほ ど差異がなく、よく類似したかたちを示している. これは高松市，坂出市を表わす成分と異なる点であ， るが，この原因としては都市の機能分化が考えられ る.すなわち，機能分化があまり進んでいない場合 には，都市のあらゆる機能が特定の地区に集中し， その結果あらゆる交通目的において，その地区が重 要な着地区となる.したがって，丸亀市の場合には 都市機能が未分化であるためこのような結果になっ 
たものと考えられる. 一方, 重要な発地区はこれら 重要な着地区がすべて含まれ，その重要度も高く， ここでも重要な着地区間相互で業務交通がなされる ことが指摘できる.

以上のことから, 業務交通の流動パターンの特性 として以下の諸点が指摘できる.

1. 業務交通においては，商業活動であれ，工業 活動であれ，経済活動の活発な地区が重要な着地区 となり, 必ずしも通勤交通において重要となった着 地区とは一致しない, 重要な発地区は, 重要な着地 区とほぼ一致し, 業務交通は重要な着地区間相互で 主に交通が行なわれる。

2. 一般に，通勤交通の重要な着地区と業務交通 のそれとは必ずしも一致しないが，都市機能が未分 化な場合には両者は一致する傾向があり，したがっ て流動パターンも類似したものとなる。

5. 全文通目的 99 のパターン

全交通目的に対する主成分分析の結果とそれから 求められた流動パターンは，それぞれ第 1 表および 第6図に示す.

第 1 成分に着目したとき，成分係数の大きい地区 は, 瓦町, 寿町, 城東町, 朝日町などを中心に 80
の高松市内の地区が抽出されている.これらの地区 は，いずれもすでに示した交通目的のいずれか，あ るいは複数の交通目的にわたって重要となった地区 であるが，とくに業務交通に打いてはこれらの地区 はすべて重要となっている. この結果は, 業務交通 の全交通目的に寄与する割合の大きさを示唆するも のと考えられるが，抽出された着地が都心部のみに 限定されている点に注目すれば，他の交通目的も全 交通目的にかなりの寄与をしているものと考えてよ いであろう. 重要な発地区は, これら都心部の重要 な着地区と郊外部の 2,3 の地区とから形成されてお り，流動パターンはさほど広くない：この点は通勤 交通が郊外部に重要な発地区を数多く有していたの と異なる点であり, その結果, 流動パターンも通勤 交通のそれとは著しく異なり，さらに他の交通目的 の流動パターンとも一般的に異なる.

第 2 成分と相関の高い地区は, 京町, 青葉町, 白 金町, 入船町, 谷町, 築港町, でありこれらは坂出市 の中心部を表わす．これらの地区も第 1 成分の場合 と同様，すべてが業務交通に拀いて重要な着地区と なって抢り，したがって第 2 成分でも第 1 成分で指 摘した全交通目的の特性がみられる. 細部にわたっ

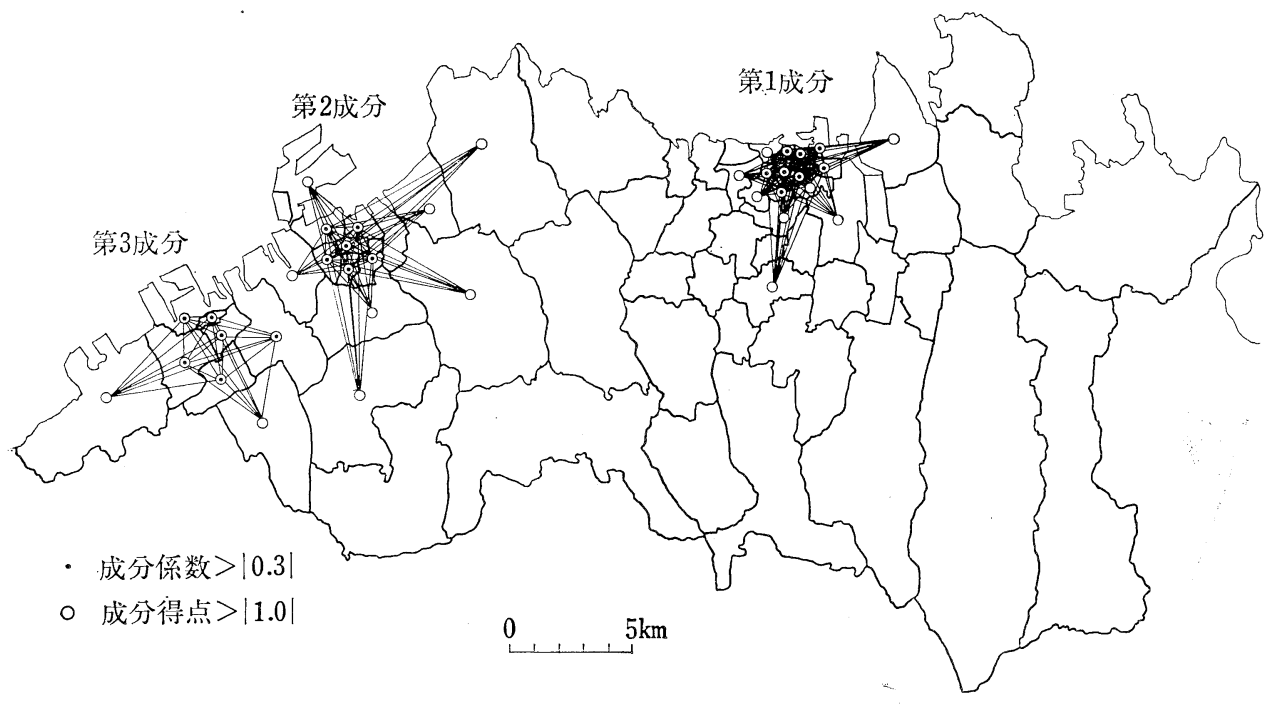

第 6 図全目的流動パターン 
て注目される点は, 業務交通で重要な着地区となっ た番の州町が全交通目的では重要な着地区となって いないことである. このことは第 1 成分の個所でも 指摘したように，業務交通の全交通目的に寄与する 割合は高いが，業務交通のみでは必ずしも全交通目 的において重要な着地区とはなりえない一例を示し ているものと考えられる. 重要な発地区はこれら重 要な着地区以外にいくつかあるが，とくに重要なも のは重要な着地区とそれに隣接する地区であり，実 質的流動パターンはさほど広くない.

第 3 成分と相関が高い地区は，富屋町，一番町， 北平山町などの丸亀市の地区であるが，ここでも土 器町以外はすべて業務交通で重要な着地区となって 打り，第 1 ，第 2 成分と同様な傾向がみられる。さ らに特徴的なことは，第 3 成分の重要な着地区は私 事交通のそれと完全に一致しているということであ る.このことは，既述したように丸亀市の都市機能 の未分化と密接な関係があるものと考えられる.す なわち，都市機能の未分化な都市においては，あら ゆる機能が特定の地区に集中・混在するため，ある 交通目的に掞いて重要となった着地区は他の交通目 的においてもまた重要な着地区となる。したがって, 丸亀市の場合, 全交通目的の流動パターンと私事, 業務交通のそれとはよく類似したものとなっている.

以上のことから, 全交通目的の流動パターンの特 性として以下の諸点が指摘できる.

1. 一般に全交通目的の流動パターンは, 他の個 々の交通目的のそれとは類似しない.しかしながら， 都市機能が地域的に未分化な場合には，全交通目的 の流動パターンは私事, 業務交通のそれと類似して くる.これは, 都市の機能が地域的に未分化な場合 には，ある特定の地域にあらゆる機能が集積・混在 するため，あらゆる交通目的において，それらが重 要な発・着地になるためと考えられる.

2. 全交通目的の重要な着地区は, 他の個々の交 通目的のそれとは一致しないが，それらはすべて業
務交通において重要な着地区であり，このことは業 務交通が全目的の交通に重要な役割を果たすことを 示している.

3）流動パターンの目的別比較

前節では，主成分分析を適用して流動パターンを 設定し，それに基づいて交通流の諸特性について目 的別に考察を加えてきた. そこでは主に個々の交通 目的ごとに考察がなされており，相互比較という観 点からの考察はあまりなされていない，そこで本節 では，若干の統計的手法ならびに主成分分析の結果 を用いて，相互比較という観点よりマクロ的に各交 通目的の特性の差異を明らかにする.

まず，上位 3 成分として抽出された高松市，丸亀 市，坂出市の中心部の都市圈全体に占める役割の大 きさを交通目的別に考察する. この考察のために， 本研究では流動パターンが包含する地域の範囲（流 動パターンの広がり）と主成分分析から得られる変 動説明量を用いた．前者については，これを間接的 に表わすむのとして，ある単位地区で発生するトリ ップが自地区内で吸収される割合（単位地区内久卜 リップ比率）と，重力モデルの距離にかかるパラメ 一タの值を用いた．これらの統計量は，いずれも上 述の 3 市の中心部の役割の大きさを表わす操作上の 定義である.

第 2 表は交通目的別の単位地区内々トリップ比率 の平均值を示しているが，これによると，通勤交通

第 2 表 単位地区内々トリップ比率

\begin{tabular}{|c|c|c|c|c|}
\hline 交通目的 & 通 勤 & 通 学 & 私 事 & 業務 \\
\hline 比 率 & $25.1 \%$ & 48.1 & 54.8 & 43.3 \\
\hline
\end{tabular}

第 3 表 分散分析表

\begin{tabular}{c|r|r|r|r}
\hline & 平方和 & 自由度 & 平均平方 & $F$ 值 \\
\hline 目的間 & 3.257 & $4-1=3$ & 1.086 & $6.92^{* *}$ \\
目的内 & 9.706 & $66-4=62$ & 0.157 & \\
\hline & 12.963 & $66-1=65$ & &
\end{tabular}

$F_{3,62}(0.01)=4.12<6.92$

表中の 66 は単位地区の数, 4 は交通目的の数を表わす. 
が最小值を，私事交通が最大值を示し，他の交通目 的は両者の中間にある. この平均値に対する分散分 析の結果（第 3 表）は危険率 $1 \%$ で棄却された。こ のことは，平均値間には統計的に有意な差異がある こと，すなわち流動パターンの広がりが交通目的間 で差異があることを間接的に表わしているものと解 䣋できる.

このように総体として差異があることが認められ た流動パターンが，交通目的別にいかに異なるかを さらに重力モデルを用いて検討した，具体的には， 距離にかかわるパラメータとは距離の変化率に対す る分布交通量の変化率を意味するので，このケ值が 交通目的別にいかに異なるかを検討した，值がこ のような性質を有することは，次に示す重力モデル の両辺を $d_{i j}$ で微分して整理すると,

$$
r=-\left[d\left(T_{i j}\right) / T_{i j}\right] /\left[d\left(d_{i j}\right) / d_{i j}\right]
$$

なる関係式が得られることにより明らかである. 解 析には次式で示される重力モデル年)を使用した。

$$
T i j=\alpha \frac{\left(G_{i} \cdot A_{j}\right)^{\beta}}{d_{i j^{r}}}
$$

ここで, $T_{i j}: i$ から $j$ への分布交通量, $G_{i}$ : 単位 地区 $i$ の発生交通量, $A_{j}$ : 単位地区 $j$ の吸収交通量, $d_{i j}: i, j$ 単位地区間距離, $\alpha, \beta, \gamma:$ パラメータ.

解析の結果を第 4 表に示すが，これより明らかな ことは， $\gamma$ 值は通勤交通で最小值，私事交通で最大 值を取り, 他の交通目的は両者の中間に位置すると いうことである．r值が大であれば距離の変化に対 して分布交通量の変化は大となり, 一方, $\gamma$ 值が小 であ札この逆の関係となる。したがって，通勤交 通では，距離が増大してもそれほど分布交通量は低

第 4 表 パラメータの值

\begin{tabular}{c|c|c|c|c}
\hline & $\alpha$ & $\beta$ & $\gamma$ & 重相 䦕 \\
\hline 数 \\
\hline 通
\end{tabular}

\begin{tabular}{|c|c|c|c|c|}
\hline & $\frac{\text { 上 位 }}{3}$ 成分 & 第 1 成分 & 第 2 成分 & 第 3 成分 \\
\hline 通 勤 & $30.6 \%$ & $18.4 \%$ & $6.5 \%$ & $5.7 \%$ \\
\hline 通 学 & 17.9 & 7.9 & 5.2 & 4.8 \\
\hline 私 事 & 14.0 & 6.1 & 4.4 & 3.5 \\
\hline 業 務 & 24.0 & 13.2 & 6.2 & 4. 6 \\
\hline
\end{tabular}

第 5 表交通目的別変動説明量

減せず，逆に私事交通では，距離の増大に伴い分布 交通量が急激に低減する，すなわち，通勤交通にお いては広範囲にわたって交通が行なわれて, 流動パ ターンの広がりが大きくなるのに対し，私事交通で は比較的狭、範囲内でしか交通が行なわれずに，流 動パターンの広がりが小さくなることを示している。 この関係を変動説明量からみたのが第 5 表の第 2 欄である.ここで上位 3 成分の変動説明量が高いと いうことは，3市の中心部が都市圈全体に及ぼす影 響の程度が高いことを示している. 結果から明らか なように，通勤交通で最大值を，私事交通で最小值 を示している。

以上の流動パターンの広がりと変動説明量に対す る考察より, 高松市, 丸亀市, 坂出市の 3 市の中心 部全体が都市圈全体に及ぼす影響の程度は, 交通目 的により異なり，通勤交通で最大で私事交通で最小 であることが明らかとなった.

次に，3市の中心部が各交通目的においてそれぞ れ個別に都市圈全体でどのような役割を果たしてい るかをみたのが第 5 表の右 3 欄である. その結果, 通勤，業務交通においては，高松市中心部（第 1 成 分）が坂出市，丸亀市の中心部（それぞれ第 2 成分 と第 3 成分）に比較してその役割が非常に高いこと， 通学，私事交通においては 3 市間にそれほど差異が ないことが明らかになった。

\section{V 流動パターンと都市構成の関係}

\section{1）目的と分析方法}

前章に执いては，交通目的別の流動パターンの諸 特性を考察し，さらにその差異を明らかにした. こ 
第 6 表＼cjkstart偏回帰係数および標準偏回帰係数一覧表

\begin{tabular}{|c|c|c|c|c|c|c|c|c|c|c|c|}
\hline \multicolumn{2}{|c|}{ 交通目的 } & $\mid$\begin{tabular}{|l}
$\mid$ 偏回帰 \\
係 数
\end{tabular} & 定数項 & $X_{1}$ & $X_{2}$ & $X_{3}$ & $X_{4}$ & $X_{5}$ & $X_{6}$ & $X_{7}$ & $X_{8}$ \\
\hline \multirow{4}{*}{ 通 勤 } & 発 生 & $\begin{array}{l}b \\
b^{\prime}\end{array}$ & 65.40 & 0.368 & $\begin{array}{l}-0.355 \\
-0.159\end{array}$ & & & & -0.724 & & 0.422 \\
\hline & \multirow{3}{*}{ 吸 収 } & & & & & & & & & & \\
\hline & & $b$ & -49.30 & -0.025 & & 0.862 & & & -1.247 & 0.059 & \\
\hline & & & & -0.030 & & 1.118 & & & -0.136 & 0.025 & \\
\hline \multirow{4}{*}{ 通 学 } & \multirow{2}{*}{ 発 生 } & $b$. & 21.11 & 0.192 & & & 0.049 & & & & \\
\hline & & $b^{\prime}$ & & 0.951 & & & 0.088 & & & & \\
\hline & \multirow{2}{*}{ 吸 収 } & $b$ & 16.90 & & & & 0.956 & & 0.037 & & \\
\hline & & $b^{\prime}$ & & & & & 0.995 & & 0.022 & & \\
\hline \multirow{4}{*}{ 私 事 } & \multirow{2}{*}{ 発 生 } & $b$ & -661.43 & 0.341 & & 0.653 & 0.325 & & 2.713 & -0.297 & \\
\hline & & $b^{\prime}$ & & 0.217 & & 0.682 & 0.130 & & 0.236 & -0.070 & \\
\hline & \multirow{2}{*}{ 吸 収 } & $b$ & -555.59 & & 2.599 & 0.439 & 0.716 & & 15. 297 & -0.922 & \\
\hline & & $b^{\prime}$ & & & 0.069 & 0.271 & 0.148 & & 0.788 & -0.100 & \\
\hline \multirow{4}{*}{ 業 務 } & \multirow{2}{*}{ 発 生 } & $b$ & -42.22 & 0.064 & 0.737 & 0.702 & & -0.303 & 1.058 & -0.226 & 0.763 \\
\hline & & $b^{\prime}$ & & 0.079 & 0.090 & 0.933 & & -0.098 & 0.118 & -0.099 & 0.048 \\
\hline & \multirow{2}{*}{ 吸 収 } & $b$ & 366.19 & & & 0.792 & & -0.430 & & -0.167 & 2.106 \\
\hline & & $b^{\prime}$ & & & & 1.057 & & -0.140 & & -0.078 & 0.072 \\
\hline \multirow{4}{*}{ 全目的 } & \multirow{2}{*}{ 発 生 } & $b$ & -873.41 & 1. 226 & -1.911 & 1.686 & & -2.122 & & & 2.017 \\
\hline & & $b^{\prime}$ & & 0.568 & -0.092 & 0.887 & & -0.200 & & & 0.055 \\
\hline & \multirow{2}{*}{ 吸 収 } & $b$ & -1963.10 & & & 2. 515 & 1.510 & -1.571 & 10. 031 & & 26.032 \\
\hline & & $b^{\prime}$ & & & & 0.794 & 0.127 & -0.087 & 0.267 & & 0.054 \\
\hline
\end{tabular}

$X_{1}$ : 夜間人口 $X_{2}$ : 非都市的職業従業者数(昼間人口) $X_{3}$ : 都市的職業従業者数(昼間人口) $X_{4}$ : 学生 -生徒数 $X_{5}$ : 第 2 次産業従業者数(昼間人口) $X_{6}$ : 商店数 $X_{7}$ : 都市的土地利用面積 $X_{8}$ : 農林床面積. bは偏回帰係数, $b^{\prime}$ は標準偏回㷌係数を示す.

れは前述したように，多様な都市構成要素が空間的 に偏在し，特定の構成要素相互を結合させるために 特定の目的をもった交通が発生・吸収するためであ ると考える. 本章ではこの認識に立って，抽出され た主要な発・着地についてその地域特性を取り上げ， それと流動パターンとの有意な関係を多変量解析の 1 つの手法を用いて考察する. すなわち，目的別の 流動パターンに有意な関係をもつ地域特性がいかな るものであるか，そしてその関係の状態がどうであ るかを明らかにする.

解析に用いた手法は重回帰分析法であり, 説明変 数の選択には逐次選択法 (stepwise method) の中の 変数増減法 ${ }^{11}$ を用いた. 使用する変数としては，当 初 42 の変数を考えたが，重共線性の問題 ${ }^{12)}$ もあり, 相互に相関が高い変数についてはどちらか一方を除
去し，残りの変数群に対して重回帰分析を適用した. さらに, 変数群の選択に際しては, あらかじめ発生 交通と吸収交通の場合とを区別せず，両者に対して 同一の変数群を使用した。これは, 変数増減法の結 果として発生・吸收交通量をそれぞれ説明する変数 群が，全変数群の中より選択されると考えたからで ある. 解析に用いた変数群 ${ }^{13}$ は第 6 表に示すとおり である.

一方, 従属変数としては, 交通目的別の発生・吸 収交通量を用いたが，全地区についてのそれではな く, 各交通目的の上位 3 成分において重要となった 発・着地に限定した，その理由は，各交通目的別の 上位の成分において重要となる発・着地を対象にす れば，目的別発生・吸収交通量を明確に説明する要 因が適切に選択可能であると考えたからである．ま 
た，選択された变数間の相対的重要性に関しては, 標準偏回帰係数を求めて独立変数の従属変数に対す る寄与の程度を考察した ${ }^{14)}$.

2）発生交通と都市構成

前節で示した従属变数と独立变数に対して変数増 減法を適用して抽出された変数，ならびにその変数 に対する偏回帰係数，標準偏回帰係数を第 6 表に示 す.

まず通勤交通に着目すると，4つの変数が抽出さ れているが，夜間人口以外は寄与の程度は非常に低 い．したがって，通勤交通は夜間人口により発生交 通量の変動の大部分が説明されると考えられる. 本 研究は人間の交通流を取り扱っているのであるから， 夜間人口は通勤交通の発生量を表わす要因と考えら れ，われわれの常識と一致する，通学交通において は，夜間人口と学生・生徒数が抽出されているが， 学生・生徒数の寄与の程度は非常に低く, 通勤交通 と同様, 夜間人口により発生交通量の大部分が説明 されると考えられる.

私事交通では， 5 つの変数が抽出されており, 寄 与の程度が最大の变数は都市的職業従業者数, 以下 商店数, 夜間人口, 学生-生徒数の順で, 都市的土 地利用面積は寄与の程度は非常に低いしたがって， 私事交通は上位 4 変数によって発生交通量の変動の 大部分が説明されると考えられる. 業務交通は， 7 つの変数が抽出されているが，寄与の程度の高い変 数は, 都市的職業従業者数と商店数であり, その他 の変数の寄与の程度は低い. したがって, 業務交通 はこの 2 つの変数により発生交通量の変動の大部分 が説明されるものと考えられる.これら 2 変数は業 務機能の集積を表わす 1 つ指標と考えられる.

全交通目的に㧊いては，5つの变数が抽出されて いるが，寄与の程度の高い変数は都市的職業従業者 数と夜間人口である. 前者は私事，業務交通におい て, 後者は通勤, 通学交通において最大の寄与の程 度を示す変数である. このことは，交通目的を考慮
せず，総体として交通を捉えた場合，その発生交通 量に影響を及ぼす要因は各交通目的において最大の 寄与の程度を示した变数群により構成されることを 示している.

3）吸収交通と都市構成

通勤交通については，4つの変数が抽出されてい るが, 都市的職業従業者数以外はさほど重要な変数 ではないしたがって，通勤交通に扔ける吸収量は， その変動の大部分がこの変数により説明されると考 えてよいであろう. この変数は, 就業機会の大きさ を表わす 1 つ指標と考えられ妥当な結果である.

通学交通では，学生・生徒数と商店数の 2 つの変 数が抽出されているが，後者は寄与の程度が非常に 低く, 前者のみによって変動の大部分が説明されて いる.

私事交通では，5つの変数が抽出されているが， 寄与の程度が高いのは商店数と都市的職業従業者数 である.この変数は私事目的の発生交通のところで も抽出されているが，寄与の程度は吸収交通とは逆 である. しかしながら，発生・吸收とも同じ変数が 抽出されているのは注目してよい特徵である.

業務交通では，4つの変数が抽出されて打り，そ のうち寄与の程度が高いのは都市的職業従業者数で ある. 業務交通は, 発生交通においてもこの変数が 抽出されており，したがって業務交通は都市的職業 従事者のウエイトが高い地区間相互で交通が行なわ れると考えられる.

全交通目的に扩いては， 5 つの変数が抽出されて いるが，寄与の程度が高い変数は都市的職業従事者 数, 商店数, 学生・生徒数である.これらの変数は, それぞれ通勤と業務交通，通学交通で最も重要な変 数となっている.したがって，吸収交通の場合も目 的を考慮せず，総体として交通を捉えた場合には， 各交通目的に扎いて最大の寄与の程度を示した変数 群が，全目的の吸収交通に主に寄与していることが 明らかである。 
4）流動パターンと都市構成

本章の第 2 節では，発生・吸収交通と有意な関係 をもつ都市構成はいかなるものであるかを交通目的 別に考察を加えてきた．前述したように，特定の目 的をもった交通と関連のあるこれらの都市構成が空 間的に分布し，それらを結合するために特定の目的 をもった交通が発生・吸収する，その結果，総体と して目的別に異なった流動パターンが形成されるわ けである.ここでは，これまでに得られた結果に基 づいてこのような関係について考察する.

まず通勤交通については，発生側の要因として夜 間人口，吸収側の要因として都市的職業従業者数が 得られた. 機能分化が進んでいる都市においては， 一般に前者は郊外部が，後者は都心部が相対的ウエ イトが高いのに対し，機能分化の程度が低い場合に はこの傾向はそれほど顕著ではない。このような関 係が通勤交通の流動パターンの特性を形成している. すなわち, 都心部は都市的職業従業者数のウエイト が高いので重要な着地が，一方，郊外部は夜間人口 のウエイトが高いので重要な発地が位置し，その結 果，両者を結合するパターンは広範囲なものとなる。 この特性は機能分化の進んでいる都市ほど顕著であ るが，このことは高松市，坂出市，丸亀市の 3 市の 機能分化の程度と流動パターンを比較すれば明白で ある.

通学交通は, 発生側の要因として夜間人口, 吸収 側の要因として学生・生徒数が得られた.たしかに 通学交通の発生・吸収はこの両者の要因に規定され ると考えられるが，これを流動パターンの関係で考 察する場合には次の点に留意する必要がある．すな わち，学校は学区制を敷き，学区制は夜間人口との 関係で制定されるということである.このことは， 通学交通は他の目的をもった交通に比較し，移動の 自由が限定されていることを示している. その結果, 流動パターンは近接した学校群と隣接地区とを結合 するかたちで形成され，比較的狭い広がりをもった
ものとなる.

私事交通については，発生側の要因として主に都 市的職業従業者数, 商店数など, 吸収側の要因とし て主に商店数, 都市的職業従業者数などが得られて いる. 吸収側の最も重要な要因である商店数は，一 般に都心と称される限られた地域に集積しており， 一方, 発生側の最も重要な要因である都市的職業従 業者数は，地方都市に㧊いては都心とその周辺部が 相対的ウエイトが高い.したがって, 流動パターン はかなり狭い範囲に限定されると考えられるが，こ れは第 4 図からも明らかである.ささらに，吸収側で 商店数が最も重要となったのは私事交通においての みであるが，この商店の集積は一般に都心部の商店 街と称される狭い地域に限定されるのが普通である. しかし，機能分化があまり進んでいない都市では， 商店街に該当する地区は同時に他の種々の機能をも った施設が混在している. 機能分化の進んでいる都 市においては，私事交通の重要な着地が通勤，業務 交通の一部から形成されるのに対し，機能分化の遅 れている都市では両交通の重要な着地がほぼ一致す るのはこのような理由によるものと考えられる.

業務交通は，発生側の要因としては主に都市的職 業従業者数，商店数など，吸収側の要因としては主 に都市的職業従業者数が抽出されている.とくに都 市的職業従業者数が発生・吸収とも寄与の程度が最 大であり，このことより業務交通は業務機能が集積 している地区間相互で結合関係がみられ，しかも重 要な発・着地はほぼ一致すると考えられるが，この ことは第 5 図に明確に示されている。

全目的の交通においては，発生側の要因として主 に都市的職業従業者数，夜間人口など，吸収側の要 因としては主に都市的職業従業者数, 商店数などが 抽出されている。すなわち，発生・吸収側とも各交 通目的に祆いて寄与の程度の最大となった变数群が 抽出されている. このことは，全目的の流動パター ンが個々の交通目的の流動パターンを複合したかた 
ちで示されることを表わしており，一般に特定の交 通目的をもった流動パターンとは一致しないと考え られる。しかしながら，業務交通と同じように，発 の生・吸収側とも都市的職業従業者数が寄与の程度 の最大の要因として抽出されていることを考えると， 全目的の重要な発・着地が業務目的のそれとかなり 一致する傾向があることが指摘できる. 前述したよ うに，この傾向は流動パターンにおいて明らかに表 われている.

\section{VI 結 論}

以上，人間の地域間交通流を媒介として都市内域 における交通流の諸特性，ならびに都市構成との関 係について考察した. その結果，以下の諸点が明ら かとなった。

1. 交通目的別流動パターンの特性

主成分分析の結果得られた流動パターンは，交通 目的別に異なった形態を示し，各交通流の特性をよ く反映している，まず通勤交通では，一般に重要な 発地は郊外部に, 重要な着地は都心部に位置し，し たがって両者を結合するパターンの広がりはすべて の目的中最大である. この傾向は都市の機能分化の 程度により異なり，機能分化の進んでいる都市ほど とくに重要な発・着地がそれぞれ郊外と都心に分離 して分布するが，機能分化のあまり進んでいない都 市では，両者は一致する傾向がある．通学交通では， 重要な着地は学校の存在に規定され, 重要な発地も 学区制の関係で隣接地区間に限定されるので，流動 パターンは学校を中心とする比較的狭い範囲に限定 される。

私事交通では，重要な発・着地は商店街を中心と する隣接地区間に限定され，流動パターンはすべて の目的中最小の広がりを有する. これらの重要な着 地は一般に通勤, 業務交通の重要な着地区の一部か ら形成される特徴があるが，機能分化があまり進ん でいない都市では，私事交通と通勤，業務交通の重
要な着地群はほぼ一致する傾向がある，業務交通に おいては，総体として経済活動の活発な地区が重要 な着地区となり，必ずしも通勤交通の重要な着地区 とは一致しない.しかしながら，都市機能が未分化 な場合には両者は一致する傾向があり，流動パター ンも類似する.また，重要な発地は重要な着地と一 致し，業務交通は重要な着地区間相互で主に交通が 行なわれる．全目的の流動パターンは，一般に他の 個々の交通目的のそれとは類似しないしかしここ のことは都市の機能分化の程度により異なり，その 程度が低い場合には全目的の流動パターンと私事， 業務交通のそれとは類似してくる．全交通目的の重 要な着地は，業務交通において重要となった着地群 の中から構成されており，業務交通が全目的の交通 に重要な役割を果たしている.

2. 流動パターンと都市構成

交通の発生・吸収に関係する都市構成要因が第 6 表に示すようなかたちで交通目的別に明らかとなり， その結果，流動パターンと都市構成との関係の状態 が把握できた。 それらを要約すると次のようになる。 通勤目的の発生交通量は夜間人口と, 吸収交通量 は都市的職業従業者数と深い関係をもつ. 一般に都 市においては，前者は郊外部が，後者は都心部が相 対的ウエイトが高いので，郊外部が重要な発地に， 都心部が重要な着地となり, 流動パターンは広範囲 なものとなる. しかし，機能分化の程度が低、場合 にはこの傾向はそれほど顕著ではない，通学目的で は，発生は夜間人口，吸収は学生・生徒数と深い関 係をもつ. 通学交通は学区制に規定され，移動の自 由が限定されるため，流動パターンは学校を中心と する周辺地区間に限定される. 私事交通では，発生 は主に都市的職業従業者数，吸収は主に商店数と深 い関係がある. 地方都市においては，後者は都心に， 前者は都心を含む周辺に集積しているため，流動パ ターンは都心を中心として狭い広がりをもったもの となる. 業務交通は発生・吸収とも都市的職業従業 
者数と深い関係がある．したがって，業務交通は業 務機能が集積している地区間相互で主に交通がなさ れ，重要な発・着地はほぼ一致する。

全目的の交通においては，発生は都市的職業従業 者数，夜間人口と，吸収は都市的職業従業者数，商 店数と主に関係がある．これらは，各交通目的の発 生・吸収交通において最も重要となった要因である。 このことは，全目的の流動パターンは各交通目的の それが複合されたかたちで示されることを表わして おり，両者のパターンは一般に一致しない．しかし ながら，業務交通と同じように，都市的職業従業者 数が最も重要な要因として, 発生・吸収側とも抽出 されていることは，業務交通が全目的の交通に重要 な役割を果たしていることを示している，事実，全 目的の交通の重要な着地群は，業務目的のそれの一 部より形成されている.

以上を簡単に要約すれば，都市交通は交通目的別 に異なった流動パターンを形成し，かつそれらは個 々に特定の機能を有する都市構成の空間的分布と密 接に関連しているので，都市交通の側面より都市構 造を考察する場合には，この関係を十分把握する必 要がある，ということになる．これが本研究で得ら れた主要な結論である.

本論文を作成するにあたり, 筑波大学山本正三，高野 史男, 奥野隆史先生をはじめ, 筑波大学地理学教室の諸 先生, ならびに愛媛大学横山昭市先生にはいろいろと御 指導，御鞭韃を賜わりましたことを深く感謝いたします。 また，資料を快く提供していただいゔ香川中央都市圈パ ーソントリップ調查委員会, 資料収集・整理に協力いた だいた筑波大学小口千明, 愛媛大学成瀬明彦両君に対し 末箻ながら深く感謝の意を表わします。

本論文は，1977年1月日本地理学会例会にて発表した ものに修正・加筆を加えたものであり，1977年 3 月東京 教育大学に提出した博士論文の一部である.

$\left(\begin{array}{ll}(\text { 投稿 } & 1977 \text { 年 } 6 \text { 月10日 } \\ \text { 受理 } & 1977 \text { 年10月 1日 }\end{array}\right)$

注

1）この言葉は一般的にそれほど普遍化していない が，ここでは第 1 図に示す 3 市 12 町を意味する言 葉として用いる．以下これを都市圈と呼ぶ.
2）たとえば, Nystuen \& Marble (1961), Illeris \& Pedersen (1968) は電話通話回数, Goddard （1970）はタクシー流動，林 $(1974 ， 1975)$, 奥野 （1972）は自動車交通流を用いており，それぞれ 用いた流動指標が社会・経済活動をかなり反映す るものであるとしている.

3）この点については，奥野（1971）が詳しい，

4）この基準は研究対象地域，用いられる流動指標 によりいろいろと異なってくる，たとえば， Goddard（1970）は因子得点 $>|1.0|$, 因子負荷量 $>|0.3|$ であり，林（1974）は因子得点 $>|0.1|$, 因子負荷量 $>|0.2|$ をそれぞれ重要な発・着地と している.

5）固有值 1.0 が平均の寄与率（情報量）を意時する ので, 通常この值以上の成分が考察対象とされて いる.

6）人間の交通を取り扱っているので徒歩トリップ が多く，このため OD 表の主対角要素の值が他 の要素と比較して非常に大きくなり, 変量の要約 が因難となるので，固有值 1.0 以上の成分の数が 多くなる。

7）町名は単位地区内の代表的町名を示す。以下同 様である。

8）私事交通の具体的内容は，買物・社交・娱楽・ 食事・レクリエーション・私事用務であり，その うち買物だけで全体の約 $24 \%$ を占める。

9）全交通目的とは，通勤，通学，私事，業務交通 目的すべてを含めたものである.

10）重力モデルには各種のタイプがあるが，ここで は最も一般的なモデルを用いた。

11）変数增減法については，奥野ほか（1971）が詳 しい.

12）重共線性の問題とは，独立変数間に高い相関の ある場合，個々の独立変数の効果を分離して測定 することができないことを意味する.

13）変数中, 非都市的職業従業者数とは農・林・漁 業従事者数を，都市的職業従業者数とはこれ以外 の職業の従業者数を意味する。また，学生・生徒 数とは単位地区に存在する学校の学生・生徒数で ある。

14）この点に関しては奥野ほか（1971）が詳しい.

\section{文 献}

林上(1974）：地域間自動車交通流からみた名古 屋大都市圈の機能地域構造. 地理評, 47,287〜 300 .

林上(1975）：名古屋市における都市内自動車交 通流と都市の地域構造. 人文地理, $27,353 \sim 376$. 
奥野隆史（1966）：東京都区部における発生・吸収 交通に関する研究 (第二報). 地理評, 39, 251 266.

奥野隆史 (1971) : 人文地理学研究のための主成分・ 因子分析. 地理，16-1，39 46.

奥野隆史（1972）：自動車交通流からみた中京地域 の連結体系. 伊藤郷平編著『中京圈』大明堂, 255 $\sim 245$.

奥野忠一・久米 均・芳賀敏郎・吉澤 正 (1971)： 『多変量解析法』日科技連, 25 157.

Berry, B. J. L. (1966) : Essays on Commodity Flows and the Spatial Structure of the Indian Economy. Univ. of Chicago, Dept. of Geogr. Res. Pap. 111 p.

Garrison, W. L. and Marble, D. F. (1964) : Factor analytic study of the connectivity of a transportation network. Pap. of Reg. Sci. Ass., 12, 231 238.

Goddard, J. B. (1970) : Functional regions within city center: a study by factor analysis of taxi flows in central London. Tran. Inst. Br. Geogr., 49, $161 \sim 181$.

Illeris, S. and Pedersen, O. (1968) : Central piaces. and functional regions in Denmark: Factor analysis of telephone traffic. Lund Stud. in Geogr. Ser. B, 31, 1 17.

Mitchell, R. B. and Rapkin, C. (1954): Urban traffic-A function of land use. Columbia Univ. Press, New York, 226 p.

\section{A STUDY OF TRAFFIC FLOW PATTERNS IN THE URBAN AREA}

\section{Setsuo FUJIME*}

This paper is concerned with urban traffic flow patterns on the basis of investigation of the traffic flows in the central part of Kagawa Prefecture, Shikoku, in terms of trip purposes. The results of this study are as follows:

Characteristics of traffic flow patterns based on trip purposes. On the whole, there are different traffic flow patterns based on the kind of trip purposes, and each pattern has its own specific characteristics. In journey to work, the important places of origin which have high factor scores in the principal component analysis (P. C. A.) are generally located in the suburban districts, and the important places of destination which have high factor loadings in the P. C. A. are located in the center of the city. Therefore, the extent of traffic flow pattern involving journey to work is the largest of all. But this tendency varies with the degree of urbanization : a well-urbanized city has particularly important places of origin in the suburbs and those of destination in the center of the city respectively, while the particularly important places of origin are at the same time the particularly important places of destination in a poorly urbanized city. In journey to school, the extent of traffic flow pattern is comparatively small because the important places of destination are controlled by the location of schools and the important places of origin are in the neighborhood of these schools in accordance with the regulations of school district. In the trip for private purposes, the extent of traffic flow pattern is the smallest of all. Because the important places of both origin and destination are located very close to each other around a shopping district. These important places of destination consist of a part of the important places of destination for journey to work and for business

Geographical Review of Japan 50-12 700 721 1977 * Faculty of Law and Literature, Ehime
University. 
purposes in a well-urbanized city. On the other hand, the important places of destination of the trip for private purposes are nearly at the same time the important places of destination for journey to work and/or for business purposes in a poorly urbanized city. In the trip for business purposes, places which have lively economic activities result in the important places of destination and they are not always consistent with the important places of journey to work. However, in a poorly urbanized city, the important places of destination of the trip for business purposes are at the same time the important places of destination for journey to work and both movement patterns are similar to each other around a shopping district. It should be noted here that, all-purpose movement patterns (the movement patterns set up without referring to specific trip purposes) are generally different from those set up in reference to there purposes. The degree of this difference, however, varies with the progress of urbanization: when the degree of urbanization is low the all-purpose traffic flow patterns are similar to those for private or business purposes. Furthermore, the important places of destination of the all-purpose traffic consisting of a part of the important places of destination of the trip for business purposes plays an important role in the all-purpose traffic.

The relationship between traffic flow patterns and urban structures can be summarized as follows : The number of trips to work which a district generates is closely related to the population of the district, and the number of trips which a district attracts is closely related to the number of people employed in urban occupations. Since the number of inhabitants of the suburban districts is generally larger than that of the center of the city and since the number of people with urban occupations in this section is larger than that of people who have occupations in the suburban districts, the particularly important places of origin are located in the suburbs, and the particularly important places of destination in the center of the city. Consequently the occupational flow is very large in extent. If the degree of urbanization is low, however, the particularly important places of both origin and destination are mostly located in the central section of the city. In journey to school, the number of trips which a district generates or attracts is closely related to the number of inhabitants and that of students of each school in the district respecitvely. As the journey to school is regulated by the school district, the traffic flow is limited to the area around school. In the trip for private purposes, the number of trips which a district generates or attracts is closely related to the number of people with urban occupations and the number of shops and stores in the district. In a local city, the working population is concentrated in and around its central section, and the shopping districts also in the same section, so that the traffic flow is very limited in extent. In the trip for business purposes, the number of trips which a district generates or attracts is related to the number of people with urban occupations in the district. Therefore, the important places of origin are at the same time the important places of destination and the trip for business is mainly done between the districts which have accumulation of business function. In all-purpose trips, the number of trips which a district generates is largely related to its entire population and the number of 
people engaged in urban occupations in the district, and the number of trips which a district attracts is largely related to the number of shops or stores and of people with urban occupations in the district. The factors which affect the all-purpose traffic flow patterns are a mixture of the most obvious factors concerned with each of the traffic flow patterns for specific purposes. Therefore, the former pattern is, in general, inconsistent with most of the latter patterns. But considering that the number of people employed in urban occupations is extracted as a most influential factor on both sides of generation and attraction as well as on the trip for business purpose, we can point that important places of both origin and destination of the all-purpose considerably tend to be identical with that of the trip for business purpose. As stated before, this tendency distinctly appears in the movement patterns. 